\title{
Identidades religiosas nos movimentos sociais contemporâneos: os casos do MST e do MNU
}

\author{
Samuel Correa Duarte ${ }^{1}$ \\ César Alessandro Sagrillo Figueiredo ${ }^{2}$
}

\begin{abstract}
RESUMO
O processo de transição democrática no Brasil trouxe a materialização de dois grupos religiosos distintos: 1) a Igreja Católica Progressista, ligada aos movimentos contestatórios do período, especialmente MST; e, 2) o segmento afro-religioso vinculado ao movimento negro, em particular o MNU. Ambos os grupos, mesmo com características distintas, fizeram parte do repertório de luta contra a ditadura e sua herança, bem como operacionalizaram suas agendas inclusos dentro do Partido dos Trabalhadores (PT). Este artigo possui o seguinte questionamento: como essas searas religiosas díspares conseguiram reafirmar nesse percurso histórico a sua cultura religiosa e mantiveram a sua identidade para além da institucionalização política? Quanto aos procedimentos metodológicos, tratar-se-á de um trabalho qualitativo, pois visa à reconstituição histórica longitudinal procurando examinar comparativamente a articulação entre política e religião desses dois segmentos religiosos.
\end{abstract}

Palavras-chave: religião; sem-terra; afro-religião; empoderamento político.

1 Prof . Ciências Políticas/ UFT - Graduação em Ciências Sociais (UFMG) e Doutorando em Sociologia em Sociologia (UECE)

e-mail: samuelcorrea@uft.edu.br - lattes: http://lattes.cnpq.br/5350906272443743

2 Prof $f^{0}$. Ciências Políticas/UFT - Graduação em Ciências Sociais (UFRGS) e Dr. em Ciências Políticas (UFRGS). e-mail: cesarpolitika@gmail - lattes: http://lattes.cnpq. br/2127722292747646 


\title{
RELIGIOUS IDENTITIES IN CONTEMPORARY SOCIAL MOVEMENTS: THE CASE OF THE MST AND AFRO-RELIGION
}

\begin{abstract}
The process of democratic transition in Brazil brought the materialization of two distinct religious groups: 1) the Progressive Catholic Church, linked to the anti-Semite movements of the period, especially the MST; and, 2) the Afro-religious segment linked to the black movement, in particular the MNU. Both groups, even with distinct characteristics, were part of the repertoire of struggle against the dictatorship and its inheritance, as well as operationalized their agendas included within the Workers Party (PT). This article has the following question: how have these disparate religious sects succeeded in reaffirming their religious culture in this historical course and have maintained their identity beyond political institutionalization? As for the methodological procedures, it will be a qualitative work, since it aims at a historical historical reconstruction, seeking to comparatively examine the articulation between politics and religion of these two religious segments.
\end{abstract}

Keywords: religion; landless; afro-religion; political empowerment

\section{Introdução}

A construção do Partido dos Trabalhadores (PT) deita as suas raízes em heranças sociais longevas, pois a sua construção, em 1979, fora fruto, principalmente, das seguintes correntes internas, quais sejam: 1) novo sindicalismo, emergido das lutas sociais do final dos anos 1970; 2) egressos e sobreviventes das organizações armadas do final dos anos 1960; 3) novos movimentos sociais diversos de contestação ao regime militar; 4) parcelas da Igreja Católica Progressista; e, 5) movimento negro com a sua cultura de resistência da diáspora étnica religiosa (KECK, 1991). Este amalgama sui generis possuía uma mesma estratégia política que era o fim objetivo da ditadura militar e o rompimento do status quo com a passagem para a democracia.

Neste período, embora o paradigma marxista e revolucionário ainda fosse o receituário dominante para a passagem para uma próxima etapa política no Brasil; no entanto, como argumento tático para esta estratégia era necessário o somatório de forças de todos os matizes numa 
mesma agremiação partidária, mesmo que fossem os mais díspares. Assim sendo, o PT como um verdadeiro guarda-chuva político servia para este propósito. Porém, realçamos que esse amálgama trazia na sua construção uma instância de forças com ramificações muito diferentes, principalmente, as conectividades dos arquétipos religiosos com as teorias políticas internas petistas, mas que nos seus objetivos estratégicos finais visavam à mesma consecução: o fim da ditadura.

Cabe enfatizar, principalmente, no tocante aos movimentos religiosos que em sua seara política, estes eram agentes emergidos e fruto do próprio período: 1) de um lado, agregava a Igreja Católica Progressista, com os seus braços de sustentação nas Comunidades Eclesiais de Base (CEBs) e, principalmente, estes servindo de esteio ao Movimento dos Sem Terra (MST); e, 2) noutro prisma, incorporava o Movimento Negro Unificado (MNU) e o seu corolário de luta, inclusive, com a defesa da afro-religião como um patrimônio cultural do povo negro que deveria ser respeitado e preservado. Ou seja, o PT conseguia a façanha, neste período histórico, de ser plural e ecumênico, bem como mobilizava parcela de militantes a partir da luta política à construção e o fomento de identidades específicas religiosas.

Neste percurso político estas entidades religiosas conseguiram o seu protagonismo para além da sigla política e firmaram-se, principalmente, junto aos movimentos sociais num exercício dialético de reivindicação e construção de identidade própria. Como exemplificação tomamos esses dois casos paradigmáticos citados. Convém realçar que esses dois segmentos emergidos na luta deste período cresceram fortemente nas últimas décadas, especialmente, a partir do governo petista de Luiz Inácio Lula da Silva (2003-2010), uma vez que estes movimentos religiosos em comunhão orgânica com a política conseguiram assumir cargos institucionais e ministérios, dito de outro modo, conseguiram se institucionalizar e se empoderar politicamente a partir dos seus principais protagonistas.

Embora constatamos que de fato houve a institucionalização dos movimentos sociais (MST e Movimento Negro) junto as instâncias políticas, no entanto quanto aos segmentos religiosos que lhes servem de anteparo, justamente, por terem vindo de uma matriz produtora de valores próprios para além da perspectiva partidária suscitam algumas 
indagações, como por exemplo: 1) como conseguiram reafirmarem neste percurso político e histórico a sua cultura religiosa, mantendo-as em comunhão orgânica com a política e, sobretudo, firmando a sua identidade para além da institucionalização política? Tal questionamento se justifica, pois conforme amplamente estudado pela literatura que versa sobre o tema essas denominações tiveram que conjugar gramáticas diferenciadas para continuarem acionando fiéis, bem como aderentes para as suas hostes tanto no espaço político quanto religioso. Assim sendo, construímos como hipótese que a partir de um discurso inicial de ruptura com status quo e visando a transição democrática no final dos anos 1970 e início dos anos 1980 esses segmentos, a partir dos anos 1990 e 2000, conseguiram (re)elaborar a sua identidade religiosa e mantiveram os seus adeptos acionados dentro do curso religioso, assim como no campo político, a partir de novas conjugações, discursos comuns e práxis religiosas.

Nesta perspectiva, a nossa análise se desdobrará nos seguintes objetivos a fim de responder ao questionamento proposto: 1) Discutir teoricamente acerca da emergência dos movimentos sociais nas últimas décadas para além do campo político e de classe; 2) examinar a manutenção do legado da igreja católica progressista, principalmente, no lócus privilegiado do MST e as suas novas formas de assimilação da religião católica por seus aderentes; e, 3) verificar a (re)elaboração, como forma de resistência étnica, do movimento negro e da religião de matriz africana em consonância com a sua tentativa de institucionalização política. Sublinhamos que neste artigo, conforme pretendemos abordar, o campo partidário e institucional servirá apenas como uma moldura no qual o campo religioso se articulará, ou seja, não sendo o campo de estudo principal, pois o objeto é o campo religioso em perspectiva comparada, mais especificamente, do MST e a sua conectividade com as Comunidades Eclesiais de Bases (CEBs); e, do Movimento Negro com as religiões de matriz africana.

Quanto aos procedimentos metodológicos, tratar-se-á de um trabalho qualitativo, pois visa à reconstituição histórica longitudinal procurando examinar comparativamente a articulação entre política e religião desses dois segmentos religiosos, com maior ênfase, entre os anos 1980 e, especialmente, os anos 2000. Ainda, para a consecução 
deste artigo, trabalharemos com as bibliografias referentes aos elementos mais significativos do contexto político e religioso que busquem aludir à questão proposta.

\section{1) Para além da discussão de classe: os agentes sociais em movi- mentos.}

De acordo com Gohn (1997) foi a partir da crítica ao paradigma marxista ortodoxo que se passou a discutir os movimentos sociais para além da lógica das lutas de classes, incluindo temas como cultura, ideologia, cotidiano, solidariedade e identidade. Essa nova abordagem procurou definir os marcos de um modelo teórico lastreado na cultura, reconhecendo que o marxismo ortodoxo não continha as ferramentas necessárias para compreender as bases da ação coletiva. Essa mesma ótica permitirá a revisão da noção de sujeito predeterminado originado na matriz estruturalista da luta de classes e dará relevo às disputas políticas na construção dos movimentos sociais e sua relação com o mundo da vida e a sociedade civil, de modo que os atores sociais serão agora analisados tomando como referência as redes de solidariedade e identidade criadas no processo de afirmação e luta.

Neste sentido, ainda segundo a mesma autora, uma marca dos novos movimentos sociais é o acolhimento de interesses difusos e práticas sincréticas, postura perceptível mesmo quando esses movimentos possuem uma causa definida. Essa articulação com outras lutas e outras simbologias cria uma área de abrangência maior que aquela coberta pelos movimentos tradicionais focados exclusivamente na questão de classe. De igual modo rechaçam a dependência com relação ao Estado e sindicatos, focando a promoção de direitos sociais a partir da própria sociedade civil. A ação dos novos movimentos sociais recorre à mídia e organização de protestos para provocar a opinião pública como meio de pressão sobre os órgãos públicos e formação de uma consciência crítica. Nesta lógica pode-se identificar que a ideia de representação político/partidária entrou em crise abrindo caminho para ações diretas dos movimentos sociais visando difundir seus valores, promover mudanças e lutar contra exclusões. 
Esse processo de reinvenção dos movimentos sociais coloca em tela os temas da cultura e da identidade, bem como nos obriga a inserir a discussão no âmbito do capitalismo avançado. Sobre o conceito de cultura, Bauman (2012, p. 63-89) identifica três variantes distintas, quais sejam: 1) A primeira ele chama de 'noção hierárquica' e consiste na prática usual de separar entre cultura 'erudita' e cultura 'popular'. Bauman indica o consequente emprego dessa distinção para fins de exclusão/ inclusão social - a educação seria um marcador social nessa ótica. 2) A segunda ele chama de 'noção diferencial' e aponta para a diversidade cultural e a luta de poder implicada na relação entre diferentes grupos humanos - os conflitos étnicos teriam seu leitmotiv nesse processo de 'estranhamento' do outro. 3) A terceira, que o autor chama de 'noção genérica', é elaborada a partir da oposição entre 'mundo humano versus mundo natural' e coloca em questão a relação entre homem e natureza, reconhecendo como natural aquilo que 'acontece ao homem' e cultural como aquilo que 'o homem faz' - nessa perspectiva o modo de vida humano estaria diretamente ligado à forma como nos relacionamos com a natureza e criamos nossos padrões culturais.

Sobre o conceito de identidade, Hall (2006) nos alerta que as narrativas derivadas do Iluminismo entraram em declínio fazendo surgir um mosaico de identidades e assim rompendo com a visão de um sujeito unidimensional. A crise de identidade faz parte de um processo de mudança em larga escala fruto do 'descentramento' do indivíduo - o sujeito pós-moderno não possui uma essência ou uma identidade fixa. A identidade passou a ser negociada conforme transitamos nos diferentes sistemas culturais nos quais estamos inseridos.

No que tange ao capitalismo avançado, Giddens (1991, 53-54) argumenta que podemos identificar nas sociedades capitalistas um tipo especial de modernidade (e sua derivação pós-moderna) com características particulares: 1) uma ordem econômica ancorada na competição e expansão dos mercados com base na inovação tecnológica e arranjos de poder; 2) uma capacidade econômica de Estados e grupos empresariais que permite intervir na realidade em escala global; 3) a circulação do capital em busca de condições ótimas de obtenção da mais valia deixando um rastro de industrialização/desindustrialização que migra do centro rumo à periferia do sistema, mas mantendo a hegemonia e 
controle financeiro sob o jugo das grandes economias globais; e, 4) a percepção do Estado como instrumento de classe se acentua tendo em vista a formação dos trustes globais com poder de agenda sobre as decisões daquele, permitindo assim um processo de acumulação de capital ampliado.

Pelo exposto, podemos apontar que a cultura e a política palmilham o terreno das lutas sociais, no qual os diferentes projetos de sociedade se enfrentam - desde a visão neoliberal de sociedade, dominante no ocidente capitalista, até as formas comunitárias que resistem em experiências singulares. Portanto, a cultura é política quando coloca em questão as definições que norteiam a inserção das pessoas na sociedade - gênero, raça, cidadania, etc. Como afirma Álvarez $(2009,28)$ " [...] la cultura no es una esfera sino una dimensión de todas las instituciones económicas, sociales y políticas. La cultura es un conjunto de prácticas materiales que constituyen significados, valores y subjetividades".

A derrocada dos projetos nacional-populistas deu lugar à ascensão do capitalismo global, mas também do seu duplo: a emergência das "tribos" urbanas e rurais reivindicando identidade, políticas e recursos. De acordo com Escobar, Álvarez e Dagnino (apud ÁLVAREZ, 2009, p. 29) ao reconhecer o caráter político da cultura está implicado que:

[...] significados y prácticas - especialmente aquellos que, en virtud de la teoría, se han considerado marginales, de oposición, minoritarios, residuales, emergentes, alternativos, disidentes y similares, todos en relación con un orden cultural predominante determinado - pueden originar procesos cuyo carácter político debe necesariamente ser aceptado.

Aqui cabe situar o conceito de "guerras de interpretação" de David Slater (apud ÁLVAREZ, 2009, p.29-30) o qual permite desvelar o poder de produzir e interpretar códigos, signos e práticas que se tornam em ferramentas a serviço dos movimentos emergentes em busca de visibilidade e reconhecimento fora do discurso dominante.

Pensar nosso lugar no mundo exige situar no tempo/espaço latino americano e resgatar nossa formação histórica e social. As raízes profundas da América Latina residem nas colonizações, na consolidação do latifúndio e do sistema escravocrata como matriz produtiva e política, uma tríade que exerceu influência na natureza dos Estados nacionais, nas relações sociais, 
nas diferentes fases das forças produtivas e das relações de produção correntes na região, até culminar no atual estágio de desenvolvimento do capitalismo de cunho transnacional (FALS-BORDA; FERNANDES; GONZÁLEZ-CASANOVA, apud BARBOSA, 2016, p.3)

Na ótica de Barbosa (2016, p.3) os três fatores elencados (a colonização, o latifúndio e a escravidão) estão na origem das relações de classe uma vez que consubstancia a distribuição dos meios de produção e do status social reservando o lugar da elite aos invasores europeus e o papel subalterno aos nativos indígenas, os desterrados afrodescendentes e os espoliados camponeses. A resistência latino-americana deveria estar ancorada numa perspectiva epistêmica capaz de relacionar educação e práxis no escopo da ação dos movimentos sociais como expressão de agentes histórico-políticos capazes de ressignificar o passado e propor um novo ethos a partir do mundo da vida dos grupos subalternizados.

$\mathrm{Na}$ América Latina cada vez mais se reivindica a existência de outras epistemes, reconhecidas como matrizes constitutivas de outras racionalidades, as quais definem formas próprias de interpretação da realidade social e de posicionamento político. Os elementos constitutivos dos movimentos sociais indígenas e camponeses herdam referentes epistêmicos da cosmovisão, das línguas originárias, da memória histórica das lutas antepassadas, da identidade cultural, que em seu conjunto conforma uma polissemia epistêmica na sua práxis política (BARBOSA, 2016, p. 17-18).

Essa perspectiva permite apreender os movimentos sociais dentro do processo dialético teoria/ação na condição de sujeitos que promovem uma formação/educação política. Recupera-se aqui a dimensão orgânica do papel dos intelectuais conforme proposto por Gramsci na medida em que se "age pensando" e se "pensa o agir" de forma reflexiva incorporando o devir e as condições materiais de existência como constitutivo do saber e das práticas. Conhecimento e realidade não se descolam como no pensamento cartesiano pois a episteme revolucionária os apreende imbricados como aparecem aos sentidos. Portanto, a cultura seria ao simultaneamente o espaço/tempo social no qual se elaboram as práticas que reintegram homem/natureza e homem/humanidade.

A efetividade desse modelo de socialização depende da supressão das "verdades ideológicas" derivadas da "gramática normativa" iden- 
tificada por Gramsci na cultura hegemônica do capital e o questionamento aberto dos matizes culturais que evidenciam a colonização, o patriarcalismo, o racismo, o sexismo.

No enfrentamento da gramática normativa, os movimentos sociais indígenas e camponeses elaboram um léxico particular, uma gramática vivencial, consolidando seu papel histórico de movimentos educativo-políticos, de intelectuais orgânicos coletivos, no permanente desafio de disputar o terreno da linguagem (BARBOSA, 2016, p.22).

De acordo com Escobar $(2015$, p.89) os povos tradicionais e sua luta pelo território deve ser analisada a partir de dois eixos: 1) a problematização da identidade nacional quando contrastada com as matrizes culturais tradicionais; e, 2) a problematização da vida em termos materiais tendo em vista a crescente degradação da biodiversidade. Para lidar com essas questões o autor propõe uma ontologia política do território, que permite perceber os povos tradicionais como ponto de ruptura com a lógica capitalista e neoliberal. $\mathrm{Na}$ abordagem de Escobar $(2015, \mathrm{p} .91)$ a relação entre território (espaço) e ancestralidade (tempo) assume papel central na medida em que permite vislumbrar a dinâmica identitária dos povos tradicionais e de resistência das populações tradicionais.

\section{2) O MST: novas formas de resistência política e religiosa}

No âmbito das ferramentas de resistência, a religiosidade desempenha importante papel na construção identitária dos movimentos campesinos. Vamos analisar aqui o papel da mística nas ações do MST, suas potencialidades e também fragilidades. Ainda na década de 1960 a Igreja Católica iniciou um movimento de aproximação com as bases sociais pautando-se no engajamento em causas e agendas políticas em diálogo com o campo ideológico da esquerda. Desse processo seria resultante a chamada Teologia da Libertação e sua associação entre a fraternidade e a noção de luta de classes. É derivada dessa corrente a linha de pensamento e ação que propõe a "opção preferencial pelos pobres" (NETO, 2007, p. 332).

No sentido religioso "mística" é sinônimo de "mistério" e se liga à espiritualidade e ao aspecto cósmico da existência humana, justificando 
os sacrifícios terrenos pela expectativa da consumação das promessas divinas, de modo que para ser efetiva precisa derivar um ethos que reverbere num conjunto de ações verbais, físicas e psíquicas direcionadas ao plano espiritual; No sentido político, a mística evoca o carisma que há em cada sujeito social, de modo a solicitar o uso das qualidades pessoais a serviço do interesse coletivo; No âmbito dos movimentos populares, a mística é captada como parte da expressão cultural e dos seus valores constitutivos, de modo a enunciar as relações de pertencimento do sujeito em relação ao grupo social, sendo essencial para a memória da luta coletiva (CALDART et al., 2012, p 476-477).

De acordo com Silva (2010, p.1-3) a prática do MST e sua associação entre o discurso marxista e a mística ocupa lugar de destaque. De acordo com a autora a mística pode ser entendida como um arcabouço de convicções que implicam numa forma de pensar e agir sobre o mundo e que se expressa por meio de diversos símbolos com a bandeira, ferramentas de trabalho, música, etc. A questão posta, por conseguinte, é saber qual é a força que move os movimentos sociais na luta e qual o sentido dessa mística, uma vez que a celebração elaborada na mística visa conclamar a comunidade a manter a unidade na luta com vistas a objetivos futuros.

Nesse sentido, Torres (2010, p.133-134) salienta que o intercâmbio entre MST e o catolicismo popular permite mobilizar símbolos e dar visibilidade a uma luta que muitas vezes parece distante da mídia e da realidade urbana, pois julga-se que o campo é um espaço vazio e que o camponês é um elemento do passado. Atualizar a luta, sensibilizar as pessoas, fortalecer a unidade, portanto, são objetivos da mística com suas práticas rituais. Ou seja, alimentar os sonhos, projetar o futuro, não perder de vista o horizonte da luta social na qual os sem-terra estão inseridos.

A prática da mística na luta dos sem-terra remonta ao período de adesão à Teologia da Libertação na década de 1970 e a expansão das Comunidades Eclesiais de Base (CEBs) e da Comissão Pastoral da Terra (CPT) entidades nas quais já se realizava uma síntese entre doutrina cristã e análise marxista. Tal qual a igreja celebra seus santos, no movimento sem-terra se reverenciam os mártires da luta no campo: a celebração da mística ativa a memória coletiva e motiva a luta. A 
vinculação entre o plano da espiritualidade e o da política gerou práticas de formação política e um cristianismo militante: a luta pela terra prefigura a entrada no paraíso celestial. É elemento destacado a marcha como derivação da procissão, nesse caso de cunho místico-político. $\mathrm{Na}$ mística, a memória da luta é trazida à luz por meio de três elementos centrais: 1) as ferramentas de trabalho no campo; 2) os alimentos produzidos na terra; e, 3) a arte popular dos cantadores, griôs, artesãos, etc. (PINTO, 2011, p. 288-290).

De acordo com Neto (2007, p. 334-336) nos anos 1980 no Brasil as Comissões Eclesiais de Base (CEBs), conforme já realçado, tiveram destacado papel no processo de redemocratização subsidiando a formação política e assim preparando quadros para partidos (PT), sindicatos (CUT) e movimentos sociais (MST). No caso particular desse último, a luta pela terra foi sendo construída com apoio de religiosos ligados à Teologia da Libertação e atuantes na Comissão Pastoral da Terra (CPT). Essa última foi essencial para um processo de articulação da luta política em contraste com o messianismo que antecedeu - a invés de esperar uma "terra prometida" futura, colocou-se em perspectiva a construção de uma "terra sem mal" no tempo presente.

A prática da mística no seio do movimento sem-terra tem raízes nas influências religiosas e se mostrou útil para criar coesão e estimular a participação tanto nos momentos formativos e deliberativos quanto nos momentos de luta, ocupações e manifestações. No entanto, realçamos que com o passar do tempo conforme o movimento foi ganhando dimensão, o sentido da mística passou a ter um viés mais laico e menos religioso, pautado nas demandas políticas e agregação de forças para a luta. A produção de uma simbologia sem-terra se tornou meio de difusão de suas causas. Sem perder as origens místicas, procurou-se forjar um ecletismo político-religioso que mira a luta contra o Estado e o capital. Incorporando práticas oriundas da Igreja Católica, como as procissões, transmutadas em "romarias da terra" o MST assumiu uma postura redentora em vista às classes pobres no campo (NETO, 2007, p. 337-399).

O mix ideológico que permitiu a ascensão do MST é composto pelo marxismo, catolicismo popular e práticas comunitárias rurais. Isso permitiu agregar ao conceito de lutas de classes também a noção de 
fraternidade. A ideia de libertação humana no plano terreno se expressava com perfeição na luta pela terra e isso seria uma condição sine qua non para uma ordem social cristã.

Na exposição de Leite e Dimenstein (2010:269) são três os elementos que contribuíram para a emergência do MST, a saber: 1) as transformações socioeconômicas no campo, deflagradas pelo regime militar na década de 1970, e que resultaram na modernização da agricultura e desembocariam na ascensão do agronegócio na atualidade; 2) a atuação da Comissão Pastoral da Terra (CPT) que procurou estabelecer um processo reflexivo com os trabalhadores rurais excluídos pela modernização do campo; e, 3) a percepção da reforma agrária como pauta permanente da agenda política nacional, que foi incensada pela atuação do MST. A força integradora do MST reside por um lado na luta por conquistas sociais para a população campesina (terra, saúde, educação, etc) e na promoção de meios de produção de identidade (simbologia) e motivação para a luta (mística) que permitem a manutenção do encantamento do mundo, em contraposição à lógica do capital.

A mística sem-terra na análise de Nascimento e Martins (2008, p.110) tem um caráter relacional ao estabelecer a religação do homem consigo mesmo, com seu semelhante e com seu "Criador". Mas essa ação objetiva a emancipação do sujeito e não apenas uma performance ritualística. Por isso a mística tem um viés político ao ensejar o engajamento do sujeito a um projeto de sociedade no qual a terra não seja cativa do capital. A espiritualidade da mística sem-terra ensina a solidariedade (ser parte de um todo) e o companheirismo (dividir o pão) e a comunhão (o encontro com o outro), se opondo assim ao "demônio" do mercado com suas práticas de alienação, consumismo e exploração.

Nesta perspectiva, Nascimento e Martins (2008, p.117) ressaltam que a mística não é meramente contemplativa ou transcendental. Ela também é terrena e sensível ao sofrimento humano. Ela dialoga com a indignação humana diante da expulsão e morte do campesino. $\mathrm{O}$ sacrifício vicário de Cristo prenuncia a renúncia e sofrimento dos sem-terra na luta pela sua terra que mata a fome do corpo, que por sua vez prepara o espírito para a "terra sem mal" onde não haverá mais fome, nem em sua forma material ou em sua forma espiritual. 
Pelo exposto, entende-se a mística como uma prática cultural e política no MST, que é realizada de forma diversa e plural. Na organização do MST, a mística se tornou um elemento estratégico, pois nos diversos espaços em que é realizada, possui suas intencionalidades. $\mathrm{O}$ seu desenvolvimento nas diversas atividades e espaços em que integrantes do MST estão reunidos se torna um momento privilegiado em que se processam construções de representações (COELHO, 2017, p.120-121).

\section{3) O Movimento negro e a afro-religião: em busca do (re)ligar.}

Assim como a Igreja Católica junto a CEBs fomentou e auxiliou o MST em sua política em comunhão orgânica com o PT, igualmente, o movimento negro e seus setores mais politizados trilharam caminhos similares na dinâmica partidária, realçando e dando destaque à promoção da religião de matriz africana. Destacamos que a luta negra no seu processo de tentativa de emponderamento institucional deita as suas raízes há séculos e está entrelaçada na própria história do Brasil, uma vez que a exclusão da população negra tem sua origem no processo da escravidão no Brasil e da sua transmigração do continente africano para a América. Conforme já amplamente debatido na seara acadêmica, este fora um processo de degredo coletivo e forçado que implicou além do trabalho escravo, também, a coerção e cerceamento a força das matrizes religiosas tradicionais da população negra. Ainda, é sabido que a população negra cativa e sequestrada da África provêm de várias localidades geográficas e etnias diferenciadas. No entanto, ao chegarem ao Brasil perderam o direito ao seu legado constitutivo identitário étnico específico tribal, bem como religiosidade, tornando-se aos olhos dos colonizadores apenas cativos degredados e sem história.

Mesmo com a passagem do Brasil Império para uma nação republicana democrática e com liberdades civis, no final do século XIX, no entanto, houve pouca mudança qualitativa, de fato, para a população negra, uma vez que ficaram à margem da nascente economia capitalista brasileira. Neste momento, passaram a funcionar os condicionantes políticos da República Velha (1889-1930), herdeira do velho estamento brasileiro, que se preocupava muito mais em acomodar os imigrantes estrangeiros do que dar cidadania para a população negra 
liberta (FAORO, 1958). Em síntese, era a nascente sociedade de classe brasileira, mas que já possuía como política de Estado uma tentativa de um 'embranquecimento' e ocultação da herança negra escravizada, pois já objetivava em seu projeto a noção política de uma falsa democracia racial (SEYFERTH, 2002).

Nesta quadra histórica as práticas religiosas de origem afro-brasileira eram caso de polícia, englobando criminalmente todas as religiões de cunho mediúnico, inclusive os espíritas, ficando todos sobre uma mesma rubrica criminal (GIUMBELLI, 1997). Pois, a religião dominante no Brasil era o catolicismo, considerada, portanto, como a religião oficial do país. Por conseguinte, qualquer tentativa que visasse um exercício ou legalização da religião de matriz africana era caso de polícia com prisão dos seus adeptos. Igualmente, torna-se importante frisar que não existia o constructo social de luta negra ou mesmo movimento negro, que visasse a articulação da defesa da política e da legalização da religião africana, ficando, por conseguinte, esses segmentos religiosos a mercê de uma política de estado altamente discriminatória.

Convém realçar que embora existisse a tentativa da construção de uma Frente Negra já a partir da década de 1930, a mesma fora severamente reprimida, principalmente, a partir de 1964 com o advento da ditadura militar (1964-1985), que visou à criminalização de qualquer tentativa de mobilização tanto por raça quanto por classe. Justamente por isso a religião de matriz africana continuava sendo, também, objeto de repressão; porém, com o passar do tempo a partir dos anos 1970 fora mais tolerada, em face de um processo cultural mais ampliado.

Sendo que, convém realçar que no final dos anos 1970 a religião de matriz africana em conjunto com o movimento negro iria finalmente se encontrar de maneira orgânica na construção do Movimento Negro Unificado (MNU), em 1978. Desta forma, reunindo-se numa mesma seara organizativa militantes políticos e dirigentes afro-religiosos, que buscavam operacionalizar numa mesma organização com vistas a romper o racismo vigente no Brasil, buscavam reparações históricas e tentavam a formatação de uma identidade racial, principalmente, tendo como elo de comunhão preponderante a religião afro-brasileira. 
É, portanto, como corolário do processo de consolidação de uma nova identidade social e cultural para o negro brasileiro que a pertença, ou pelo menos proximidade, com as religiões afrodescendentes passa a ser vista como parte constitutiva do "ser negro" (OLIVEIRA, 2011, p. 52)

Esses agentes precisaram se articular acima das fronteiras invisíveis da religião e da falsa democracia racial brasileira sob uma rubrica política que os amparasse neste momento político. Logo, o PT serviu como plataforma política de sustentação para as ações da população negra. Devemos realçar que desde o início a religião de matriz africana tornou-se um paradigma para o movimento negro, conforme citado, uma vez que mesmo que muitos militantes do MNU não fossem afro-religiosos, por si só o fato de defender um legado religioso africano representava, obviamente, reivindicar uma herança usurpada pela escravidão. Assim sendo, mesmo com todas as diferenças políticas e ideológicas do período em curso no Brasil, principalmente em face do final da ditadura miliar, o elemento religioso africano servia como elo aglutinador e uma herança étnica comum: seria a volta ao eldorado africano.

Nesse contexto, os movimentos sociais negros incorporam em suas narrativas políticas as comunidades religiosas de matriz africana como parte relevante das lutas históricas de emancipação negro-africana no Brasil, um mito de origem que define uma ancestralidade difusa. A identidade "afropopular" ou "negro-africana" implica a equivalência entre as diversas identidades sociais, políticas ou religiosas, do campo afro-brasileiro (SALES JR., 2009, p. 129).

A partir da década de 1980 em diante se constatou uma maior difusão da matriz afro-religiosa em termos culturais e políticos, sobretudo, com o advento da constituição de 1988, pois fora o momento que ficara legislado na Carta Magna os crimes atribuído ao racismo e a intolerância religiosa. Porém, a população negra ainda estava longe da sua representatividade política, ficando, ainda, muito mais na categoria de coadjuvante política, uma vez que não conseguia irromper nas urnas os seus representantes políticos. Além desta falta de representatividade, também, ocorria um duplo e contraditório movimento: 1) positivo - o encontro das searas religiosas de matriz africana com as pastorais católicas, influenciando estas no formato de pastorais negras com padres 
negros vestidos de roupas africanas; e, 2) negativo, ocorria um processo de emergência das matrizes religiosas neopentecostais e uma perseguição com práticas de violência simbólica, física e institucional destas com os terreiros, os pais de santos e os seus fiéis (MARIANO, 1999).

Não obstante esses fluxos e refluxos, no início da década de 2000 , contatamos um processo singular de ascensão do movimento negro, pois era um momento de afirmação de identidade étnica, fato este que, fundamentalmente, baseava-se num processo de defesa das religiões de matriz africana. Em 2001 ocorre a Conferência de Durban, na África do Sul, esta Conferência possuía em seu cerne o combate ao racismo e a intolerância aos negros. Como política efetiva estabelece a defesa da população negra, o combate e a denúncia do racismo, assim como a preservação das religiões de matriz africana como patrimônio de um povo que precisava ser zelado na luta contra o racismo e xenofobia. Portanto, nesta Conferência se institucionaliza a defesa da religião de matriz africana em todas as suas variantes como legado de um povo e que urge a preservação, servindo, por conseguinte, de paradigma para a luta em outros países.

Em 2002 ocorre a eleição de Luiz Inácio Lula da Silva à presidência do Brasil. Neste percurso ascende politicamente todo o elenco de personagens que estavam junto ao Lula desde a origem do PT. Como política de Estado Lula cria a Secretaria de Política de Promoção da Igualdade Racial (SEPPIR), com status ministerial, ou seja, seria a coroação de todas as políticas e jogo de força final do movimento negro em todos esses anos de luta, conseguindo, finalmente a sua institucionalização política. Em seu núcleo a SEPPIR visava englobar uma série de gramáticas que objetivava a promoção da equidade racial no Brasil, em diversas políticas, por exemplo, o fomento a questão de cotas afirmativas, as políticas públicas, bem como, obviamente, a preservação da população de terreiro e de matriz africana.

Resumindo o corolário das ações políticas, destacamos as seguintes: 1) em janeiro de 2003 houve promulgação da Lei $\mathrm{N}^{\mathrm{o}}$ 10.639/033 que determina a obrigatoriedade do ensino da História e Cultura Africana e Afro-brasileira; conforme já realçado, 2) em 21 de março de 2003 foi criada a Secretaria Especial de Políticas de Promoção da Igualdade Racial (SEPPIR) com status de ministério; 3) em 2007, o 
decreto $n^{\circ}$ 6.040 20074 instituiu a Política Nacional de Desenvolvimento Sustentável dos Povos e Comunidades Tradicionais; 4) a Portaria no 992 de 13 de maio de 2009 instituiu a Política de Saúde da População Negra; e, 5) a criação do Estatuto da Igualdade Racial - Lei 12.288/2010.

Nos itens delineados embora não seja realçado claramente a articulação das políticas de Estados com o campo religioso, porém, devemos grifar que a religião de matriz africana perpassa transversalmente em todos os itens, pois subtende-se a preservação do legado africano sobremaneira através da religião afro-brasileira. Assim sendo, a partir de Lula começou a haver, de fato, uma política tanto de defesa da religião como de combate endêmico ao racismo tributário da Conferência de Durban, igualmente, começou haver a tentativa da preservação dos terreiros como patrimônios materiais e imateriais do povo negro. Neste status político os terreiros receberam a outorga de patrimônio a ser preservado, pois agregariam no seu cerne a história e a cultura identitária de um povo, portanto, começou a ocorrer políticas efetivas e consistentes de tombamento de terreiros como patrimônio público, fazendo com a questão étnica e religiosa adquirisse a centralidade da luta.

Nos últimos anos, a questão multicultural, o debate público sobre identidade e etnicidade, o uso político de conceito de cultura têm mostrado a centralidade da religião enquanto categoria definidora de pertencimento e, portanto, de papéis, identidades, trânsitos e conflitos políticos. (POMPA, 2012, p. 162).

Embora com toda a política existente de caráter de fomento a religião de matriz africana, não obstante, cumpre realçar que o Estado se manteve com a sua característica primordial de laicidade; fato este que não causa estranheza em face do fomento da cultura de matriz religiosa específica, uma vez que o objetivo principal do Estado nesta política residia na promoção da igualdade racial sob o argumento de valorização da matriz religiosa de um povo. Melhor explicando, o Estado funcionaria como um dinamizador destas políticas públicas de fomento a igualdade racial e as ações afirmativas de caráter de reparações históricas, políticas estas ambicionadas há século pela população negra. Realçamos, ainda, que essa laicidade do Estado se manteve e se materializou, de fato, quando o mesmo cumpriu o seu papel de fo- 
mentador da cidadania de uma população historicamente discriminada, sem, obviamente, fazer juízo de valor ou promover cizânia com outras correntes religiosas ou étnicas.

Finalizando, a fim de responder ao questionamento proposto, percebemos que o movimento negro mesmo tendo várias origens possuía na sua essência um objetivo comum: o fim do racismo e a denúncia da falácia da democracia racial. A luta contra a ditadura militar fora, obviamente, um pano de fundo em que os movimentos precisavam se articular para buscar legitimidade e jogo político, sendo que o PT servia perfeitamente como veículo político para esse percurso a ser seguido. Sendo que, sublinhamos, que neste percurso a busca pela identidade étnica fora alicerçada pelo reforço da (re)ligação com a religião de origem dos seus ancestrais como um elemento a ser buscado e perseguido, mesmo que aludindo a uma unidade utópico, uma vez que a religião de matriz africana no Brasil é plural e extremamente sincrética.

\section{Conclusão}

De acordo com o exposto pelo texto no processo de consolidação à democracia no Brasil tínhamos duas perspectivas religiosas marcadamente diferentes, mas que possuíam um núcleo estratégico comum: a luta contra a ditadura militar. Ou seja, possuíam origens totalmente díspares: 1) A igreja progressista, com a sua eclosão nos anos 1960 dando reforço a luta pela terra e, consequentemente, ao MST; e, 2) a luta contra o racismo desde a década de 1930 até aos anos 1970 com a formação do MNU e a repressão pela ditadura militar, dando origem as correntes do movimento negro e a valorização da religião de matriz africana.

Ainda, o que fica realçado neste percurso político e histórico é a diluição das discussões de oposição ao Estado (final da ditadura), para uma recomposição como integrante do núcleo do Estado, principalmente nas últimas décadas com a emergência da politização dos movimentos religiosos e sociais. Nesse sentido fora reforçada a questão de revalorização dos movimentos sociais e a emergência de outros valores identitários para a sua operacionalização, tais como etnicidade, luta pela terra, religião, bem como outras searas emergentes de luta no início do século XXI. 
Desta forma, percebemos neste contexto comparativamente, tanto o MST com o reforço da Igreja Católica junto as CEBs quanto o Movimento Negro com o reforço da afro-religião, precisaram necessariamente rearticular suas gramáticas de ações e discursos para se fazer presente no jogo político atual. O MST em comunhão com a igreja parte para uma mística religiosa para além da questão política, visando a construção de um novo ethos que seja capaz de romper com as relações de exploração tanto do homem quanto da natureza, articulando a convivência entre humanidade e natureza em novos termos: a ecologia de saberes, a segurança alimentar, agroecologia, etc., e dialogando com as comunidades eclesiais de base e pastorais da terra, a fim de agregar e manter adesões na sua seara. No tocante ao Movimento Negro, por sua vez, transforma a afro-religião como pedra de toque e faz da sua busca o universo de identidade de preservação de um passado visando, por conseguinte, a unidade presente do povo negro. Embora esse conjunto de ações e agentes tenham se bifurcado com o tempo em outras searas de luta, porém, há um reencontro dos mesmos através do amálgama de um governo de caráter progressista e com políticas públicas de Estados na gestão de Lula.

No tocante a seara do MST e da Igreja vemos estes colherem frutos longevos no campo político, principalmente, quando verificamos o número de políticos egressos desta seara política religiosa junto ao PT. Quanto a matriz afro-religiosa há pouca ou nula representatividade política e, mesmo como toda política de avanço do governo Lula (2003-2010), percebemos, ainda, um grande refluxo quando constatamos a existência de um amplo campo de intolerância religiosa, sobretudo, o ataque aos terreiros realizados por denominações religiosas neopentecostais. Ou seja, reiterando Mariano (1999) no quesito ao campo afro-religioso houve um processo contraditório de duas mãos: 1) se por um lado houve uma ascensão com a implementação, de fato, de políticas públicas para a valorização da cultura negra e, principalmente, religiosa; 2) por outro lado, houve uma onda reversa de ataque contra o empoderamento da religião de matriz africana, fruto, obviamente, ainda do racismo incluso e vigente na sociedade brasileira.

Concluindo, percebemos que longe de esgotar as respostas ao questionamento proposto no artigo, os caminhos trilhados da Igreja 
Progressista junto ao MST e do Movimento Negro junto a afro-religião serão respondidos pelos próprios agentes, principalmente, em face dos horizontes religiosos, assim como dos caminhos da política e da cultura nacional. Possivelmente, o MST terá que continuar buscando o seu misticismo religioso entre igreja e a luta pela terra, com o intuito da manutenção do seu ethos e ativar adeptos e atrair novos; e, quanto a afro-religião e o movimento negro terá que manter a resistência étnica religiosa como um legado e patrimônio cultural de um povo.

\section{Bibliografia}

ÁLVAREZ, S.E. Repensando la dimensión política y cultural desde los movimientos sociales: algunas aproximaciones teóricas. In: HOETMER, R. Repensar la política desde América Latina: cultura, Estado y movimientos sociales. Lima: Fondo Editorial de la UNMSM, 2009.

BARBOSA, L. P. Movimentos Sociais na América Latina e a luta por uma nova hegemonia. Conferência apresentada na Mesa "Organizações sociais e a luta por uma nova hegemonia". I JORNADA INTERNACIONAL DE ESTUDOS E PESQUISAS EM ANTONIO GRAMSCI (I JOINGG). Fortaleza, p. 1-23, 2016.

BAUMAN, Z. Ensaios sobre o conceito de Cultura. Rio de Janeiro, RJ: Zahar, 2012.

CALDART, R. S.; PEREIRA, I. B.; ALENTEJANO, P.; FRIGOTTO, G. Dicionário da Educação do Campo. São Paulo: Expressão Popular, 2012.

COELHO, F. A prática da mística e a construção de uma memória histórica no MST. Hist. R., Goiânia, v. 22, n. 1, p. 119-138, jan./abr. 2017.

ESCOBAR, Arturo. Territorios de diferencia: la ontología política de los "derechos al territorio". Desenvolv. Meio Ambiente, v. 35, p. 89-100, dez. 2015.

FOSTER, John Bellamy. A ecologia de Marx: materialismo e natureza. $4^{\mathrm{a}}$ ed. Rio de Janeiro: Civilização Brasileira, 2014.

FAORO, Raymundo. Os donos do poder: formação do patronato político brasileiro Porto Alegre: Ed. Globo, 1958

GIDDENS, Anthony. As consequências da modernidade. Ed. Unesp, 1991.

GIUMBELLI, Emerson. O cuidado dos mortos: uma historia da condenação e legitimação do espiritismo. Rio de Janeiro: Arquivo Nacional, 1997. 
GOHN, Maria da Glória. Teorias dos movimentos sociais: paradigmas clássicos e contemporâneos. São Paulo: Loyola, 1997.

HALL, Stuart. A identidade cultural na pós-modernidade. Rio de Janeiro: DP\&A, 2006.

HOETMER, R. Después del fin de la historia. Reflexiones sobre los movimientos sociales latinoamericanos de hoy. In: Repensar la política desde América Latina: cultura, Estado y movimientos sociales. Lima: Fondo Editorial de la UNMSM, 2009.

OLIVEIRA, Rosalira Santos. Guardiãs da identidade? As religiões afro brasileiras sob a ótica do movimento negro. Magistro - Revista do Programa de Pós-Graduação em Letras e Ciências Humanas - UNIGRANRIO, v. 2, n.1, p. 50-68, 2011.

KECK, Margaret. PT: a lógica da diferença: São Paulo. Ática, 1991.

LEITE, Jáder Ferreira; DIMENSTEIN, Magda. Movimentos sociais e produção de subjetividade: o MST em perspectiva. Psicologia \& Sociedade; 22 (2): 269-278, 2010.

MARTÍNEZ-TORRES, M.E; ROSSET, P.M. Del conflicto de modelos para el mundo rural emerge La Vía Campesina como movimiento social transnacional. El Otro Derecho 44, 2012, p. 21-58.

MARIANO, Ricardo. Neopentecostais : sociologia do novo pentecostalismo no Brasil. São Paulo : Loyola, 1999.

NASCIMENTO, Claudemiro Godoy do; MARTINS, Leila Chalub. Pedagogia da mística: as experiências do MST. Emancipação, Ponta Grossa, 8(2): 109120, 2008. Disponível em http://www.uepg.br/emancipacao

NETO, Antonio Julio Menezes. A Igreja Católica e os movimentos sociais do campo: a teologia da libertação e o movimento dos trabalhadores rurais sem terra. CADERNO CRH, Salvador, v. 20, n. 50, p. 331-341, Maio/Ago. 2007.

PINTO, João Rodrigues. Metáforas da luta pela terra: a mística do MST. Linguagens - Revista de Letras, Artes e Comunicação. Blumenau, v. 5, n. 3, p. 287-301, set./dez. 2011.

POMPA, Cristina. Introdução ao dossiê religião e espaço público: repensando conceitos e contextos. Religião e Sociedade, Rio de Janeiro, v. 32, n. 1, p. $157-166,2012$

SALES Jr., Ronaldo. Políticas de Ancestralidade: negritude e africanidade na esfera pública. Caos - Revista Eletrônica de Ciências Sociais, João Pessoa, n. 14 , p 119- 133, set. 2009

SEYFERTH, Giralda. Colonização, imigração e questão racial no Brasil. Revista USP, São Paulo, n.53, p. 117-149, março/maio 2002 
SILVA, L.C.S. A Mística Sem Terra: Espaço de Formação Popular. Anais XVI Encontro Nacional dos Geógrafos. Realizado de 25 a 31 de julho de 2010. Porto Alegre - RS, 2010.

TORRES, Cristine Lima. O simbolismo do MST na marcha e na mística: espaço itinerante de formação humana. Revista Espaço Acadêmico, no. 110 - julho de 2010. 